\title{
Odpowiedź autorki na komentarz T.M. Zielonki „Czy pierścień naczyniowy był przyczyną duszności?"
}

\author{
Reply to commentary T.M. Zielonka: "Was vascular ring the cause of dyspnea?" \\ Praca nie była finansowana
}

Pneumonol Alergol Pol 2015; 83: 238-239

Dziękuję za komentarz i wnikliwą analizę przedstawionego przypadku. W historii choroby opisywanego pacjenta podałam informację, że od wielu lat był pod opieką poradni kardiologicznej z dotychczasowym rozpoznaniem choroby niedokrwiennej mięśnia sercowego i napadowych zaburzeń rytmu. W tej informacji zawarta jest wieloletnia obserwacja i przeprowadzona szeroka diagnostyka.

W kilkukrotnie powtarzanych badaniach echokardiograficznych stwierdzano odcinkowe zaburzenia kurczliwości mięśnia sercowego utrzymujące się na tym samym poziomie od wielu lat. Wykonano koronarografię, w której nie stwierdzono zmian wewnątrznaczyniowych, nie wykonano żadnej interwencji. Mimo że w badaniach dodatkowych nie stwierdzono nowych zmian, od pewnego czasu pacjent zgłaszał nasilenie duszności i dlatego z poradni kardiologicznej pacjent został skierowany do diagnostyki pulmonologicznej. Duszność ulegała nasileniu w trakcie wysiłku, ale pacjent zgłaszał również problemy w spoczynku, w pozycji stojącej i leżącej bez istotnej różnicy. W skali MRC stopień 2 . Nie obserwowano obrzęków na kończynach dolnych, nie stwierdzano objawu wątrobowo-szyjnego. Czynność serca w trakcie wizyt 80-90/min, ciśnienie tętnicze 120/70, 130/70 a więc w granicach normy, szmer pęcherzykowy prawidłowy nad obu polami płucnymi. Saturacja 98\%, badanie gazometryczne prawidłowe, wyniki badań dodatkowych w granicach normy. Chory nie pali i nie palił w przeszłości, nie zgłaszał kaszlu, nie podawał żadnych objawów ze strony przewodu pokarmowego (braku apetytu, dysfagii, wymiotów). Pacjent ma nadwagę - $112 \mathrm{~kg}$, czyli BMI 36,16, co oznacza II stopień otyłości. Obraz radiologiczny klatki piersiowej, wstępnie sugerujący niewydolność krążenia, został zweryfikowany w badaniu komputerowym, w którym stwierdzono prawidłową strukturę miąższu płucnego, naczynia płucne o prawidłowych wymiarach oraz obecność wcześniej dokładnie opisanego ringu naczyniowego.

Pełną diagnostykę pacjenta wykonano przed podjęciem decyzji o opublikowaniu tego nietypowego przypadku. W wykonanych badaniach obrazowych - RTG i komputerowym klatki piersiowej, także i spirometrycznym, nie stwierdzono objawów ucisku na tchawicę i/lub na przełyk.

W badaniu spirometrycznym wskaźnik Tiffeneau $\mathrm{FEV}_{1} / \mathrm{VC}-0,73$ (wiek pacjenta 71 lat), $\mathrm{FEV}_{1}-0,67$ wskazują na umiarkowane zaburzenia obturacyjne [1,2].

Wartości wskaźników maksymalnych przepływów ( MEF75, MEF50, MEF25) mogą być pomocne w rozpoznawaniu zaburzeń przepływów wydechowych tylko przy braku cech obturacji i restrykcji, a więc nie $\mathrm{w}$ tym przypadku $[3,4]$. Tym samym wskaźnik MEF50/MIF50, którego elementem jest parametr MEF50 nie ma u opisa- 
nego pacjenta wartości diagnostycznej. Powyższe zaburzenia spirometryczne utrzymywały się na tym samym poziomie $\mathrm{w}$ trakcie kilkuletniej obserwacji chorego. Próba rozkurczowa ujemna. Zaburzenia spirometryczne nie są odpowiedzialne za zgłaszaną przez pacjenta od pewnego czasu duszność. $W$ przedstawionym doniesieniu nie tylko nie podałam informacji, że przyczyną duszności są zaburzenia obturacyjne obserwowane w spirometrii, lecz stwierdziłam, że może być skutkiem zaburzeń w układzie krążenia wynikających z wieloletniego funkcjonowania pełnego (wszystkie naczynia biorące udział w przepływie krwi) pierścienia naczyniowego.

Duszność jest subiektywnym odczuciem zaburzeń oddychania o skomplikowanej i nie do końca wyjaśnionej patofizjologii. Objaw ten może być spowodowany zaburzeniami w zakresie układu oddychania, krążenia, centralnego układu nerwowego, mięśni oddechowych i innych. Pomimo stosowania różnych skal w celu przybliżenia oceny tego objawu, obiektywne określenie natężenia jest trudne i zawsze przybliżone.

W przedstawionym przypadku rozważano przyczyny w zakresie układu oddechowego i układu krążenia. Po przeanalizowaniu wyników badań nie stwierdzono przyczyny duszności w układzie oddechowym. Może ona być natomiast spowodowana zaburzeniami hemodynamicznymi w wyniku wieloletniego funkcjonowania pełnego pierścienia naczyniowego - wszystkie naczynia biorą udział w przepływie krwi.
Przedstawiłam ten przypadek jako kazuistyczny nie tylko ze względu na obecność ringu naczyniowego u pacjenta w zaawansowanym wieku, ale dlatego, że jest on utworzony z funkcjonujących naczyń, co stanowi rzadką sytuację, która musi w pewnym momencie życia (nieustannej pracy układu krążenia) prowadzić do zaburzeń hemodynamicznych. Również objawy kliniczne były przez wiele lat niejednoznaczne i dlatego po tak długim okresie obserwacji, wielu badaniach, dopiero w wyniku diagnostyki pulmonologicznej z powodu niejasnego (od wielu lat) obrazu badania rentgenowskiego klatki piersiowej i duszności, zostało postawione pełne rozpoznanie wady naczyniowej, ale duszność ma etiologię w układzie krążenia.

Jak wskazano w doniesieniu pacjent ponownie został przekazany i nadal pozostaje pod opieką kardiologiczną.

\section{Konflikt interesów}

Autorka nie zgłasza konfliktu interesów.

\section{Piśmiennictwo:}

1. Zalecenia Polskiego Towarzystwa Ftyzjopneumonologicznego rozpoznawania i leczenia przewlekłej obturacyjnej choroby płuc (POCHP). Pneumonol. Alergol. Pol. 2004; 72 (supl. 1).

2. Boros P., Franczuk M., Wesołowski S. Zasady interpretacji wyników badania spirometrycznego. Pneumonol. Alergol. Pol. 2004: 72 (supl. 2): 19-28.

3. Quanjer P.H., Weiner D.J., Presto J. J., Brazzale D. J., Boros P.W. Measurement of FEF $25-75 \%$ and FEF $75 \%$ does not contribute to clinical decision making. Eur. Respir. J. 2014; 43: 1051-1058. . doi: 10.1183/09031936.00128113.

4. Boros P. Na co nie zwracamy uwagi w spirometrii? III Krajowa Konferencja Chiesi, Warsztaty spirometryczne, Łódź 26-27 marca 2015. 